\title{
Laredo Utility Relocation Project, Chacon Creek, Webb County, Texas
}

Anthony S. Lyle

Follow this and additional works at: https://scholarworks.sfasu.edu/ita

Part of the American Material Culture Commons, Archaeological Anthropology Commons, Environmental Studies Commons, Other American Studies Commons, Other Arts and Humanities Commons, Other History of Art, Architecture, and Archaeology Commons, and the United States History Commons

Tell us how this article helped you.

This Article is brought to you for free and open access by the Center for Regional Heritage Research at SFA ScholarWorks. It has been accepted for inclusion in Index of Texas Archaeology: Open Access Gray Literature from the Lone Star State by an authorized editor of SFA ScholarWorks. For more information, please contact cdsscholarworks@sfasu.edu. 


\section{Laredo Utility Relocation Project, Chacon Creek, Webb County, Texas}

Creative Commons License

(c) (i) @ (9)

This work is licensed under a Creative Commons Attribution-NonCommercial 4.0 International License 


\section{Laredo Utility Relocation Project, Chacon Creek, Webb County, Texas}

Anthony S. Lyle

Cynthia L. Tennis

Principal Investigator

Texas Antiquities Permit No. 2436

Ccopyright 2001

Center for Archaeological Research

The University of Texas at San Antonio

Archaeological Survey Report, No. 313 
The following information is provided in accordance with the General Rules of Practice and Procedure, Chapter 41.11 (Investigative Reports), Texas Antiquities Committee:

1. Type of investigation: Intensive Survey and Monitoring

2. Project name: Laredo Utility Relocation (Chacon Creek Pipeline Crossing)

3. County: Webb

4. Principal investigator: Cynthia L. Tennis

5. Name and location of sponsoring agency: Reliant Energy Entex, 290 South Castell, New Braunfels, TX 78130

6. Texas Antiquities Permit No.: 2436

7. Published by the Center for Archaeological Research, The University of Texas at San Antonio, 6900 N. Loop 1604 W., San Antonio, Texas 78249-0658, 2001

A list of publications offered by the Center for Archaeological Research is available. Call (210) 458-4378; write to the Center for Archaeological Research, The University of Texas at San Antonio, 6900 N. Loop 1604 W., San Antonio, Texas 78249-0658; e-mail to car@lonestar.utsa.edu; or visit CAR's web site at http://car.utsa.edu. 


\begin{abstract}
In August of 2000, archaeologists from the Center for Archaeological Research (CAR) at The University of Texas at San Antonio (UTSA) were contracted to test for archaeological deposits along the route of a proposed utility pipeline relocation in Laredo, Texas. The route of the proposed pipeline relocation will impact a 690-foot $(210 \mathrm{~m})$ section along Meadow Avenue at the bridge crossing Chacon Creek, in Laredo. CAR archaeologists monitored the excavation of six backhoe trenches along the proposed relocation route in order to test for buried cultural materials. No intact cultural deposits were encountered. The majority of the tested section was disturbed from previous construction, probably associated with the earlier bridge construction activities which occurred in the project area.
\end{abstract}




\section{Contents}

Abstract fon

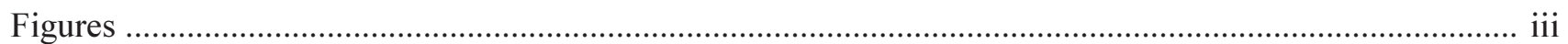

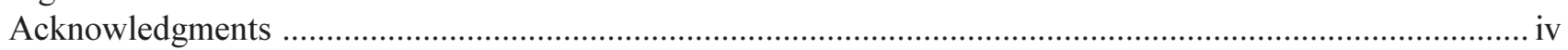

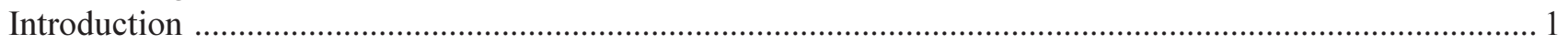

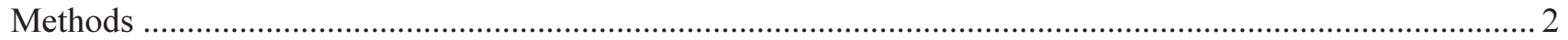

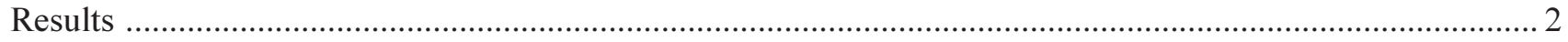

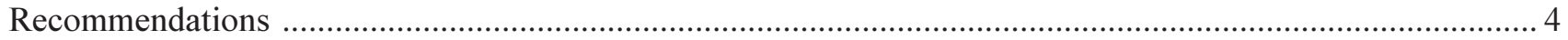




\section{Figures}

Figure 1. Map of project area with locations of backhoe trenches. ......................................................... 1

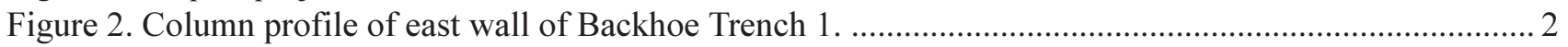

Figure 3. Column profile of east wall of Backhoe Trench 3....................................................................... 3

Figure 4. Column profile of east wall of Backhoe Trench 6..................................................................... 5 


\section{Acknowledgments}

Thanks are extended to Myles Miller (Texas Historic Commission), Tom Ley (Entex), Karl Burris (Entex), RoseMary Schoemackers (Southwestern Bell), and Juan Salinas (who served as the backhoe operator) for their time and efforts. I would like to thank Richard Jones (CAR-UTSA) for assistance with the trench profiles illustrated in this report, and also thank Richard Mahoney (CAR-UTSA) for the original hand-drawn map of the project area and for his advice. 


\section{Introduction}

In July 2000, the Center for Archaeological Research (CAR), at The University of Texas at San Antonio (UTSA) contracted with the city of Laredo, Texas and Reliant Energy Entex to conduct backhoe trenching and subsurface testing for the proposed relocation of city utilities along the right-of-way (ROW) of the existing Meadow Avenue bridge that crosses Chacon Creek. The following report will relay our findings and recommendations in regards to the proposed utility relocation route. All work was conducted under Antiquities Permit No. 2436 from the Texas Historical Commission.
CAR excavated six backhoe trenches along the proposed 690-foot (210-meter) route (as per Karl Burris, Entex) for the relocation of an Entex gas pipeline and Southwestern Bell communication line (Figure 1). Mr. Burris met archaeologists from CAR at the beginning of the fieldwork phase and outlined the proposed route for the utility trench. The contractor and backhoe operator for Entex were also present and indicated, in general, where the trench would be placed, and where previous work in the area for existing sewer/water lines had been conducted by the city of Laredo. The utility relocation trench was to be between 4 and 5 feet (1.2$1.5 \mathrm{~m}$ ) in depth for the majority of its length and up to

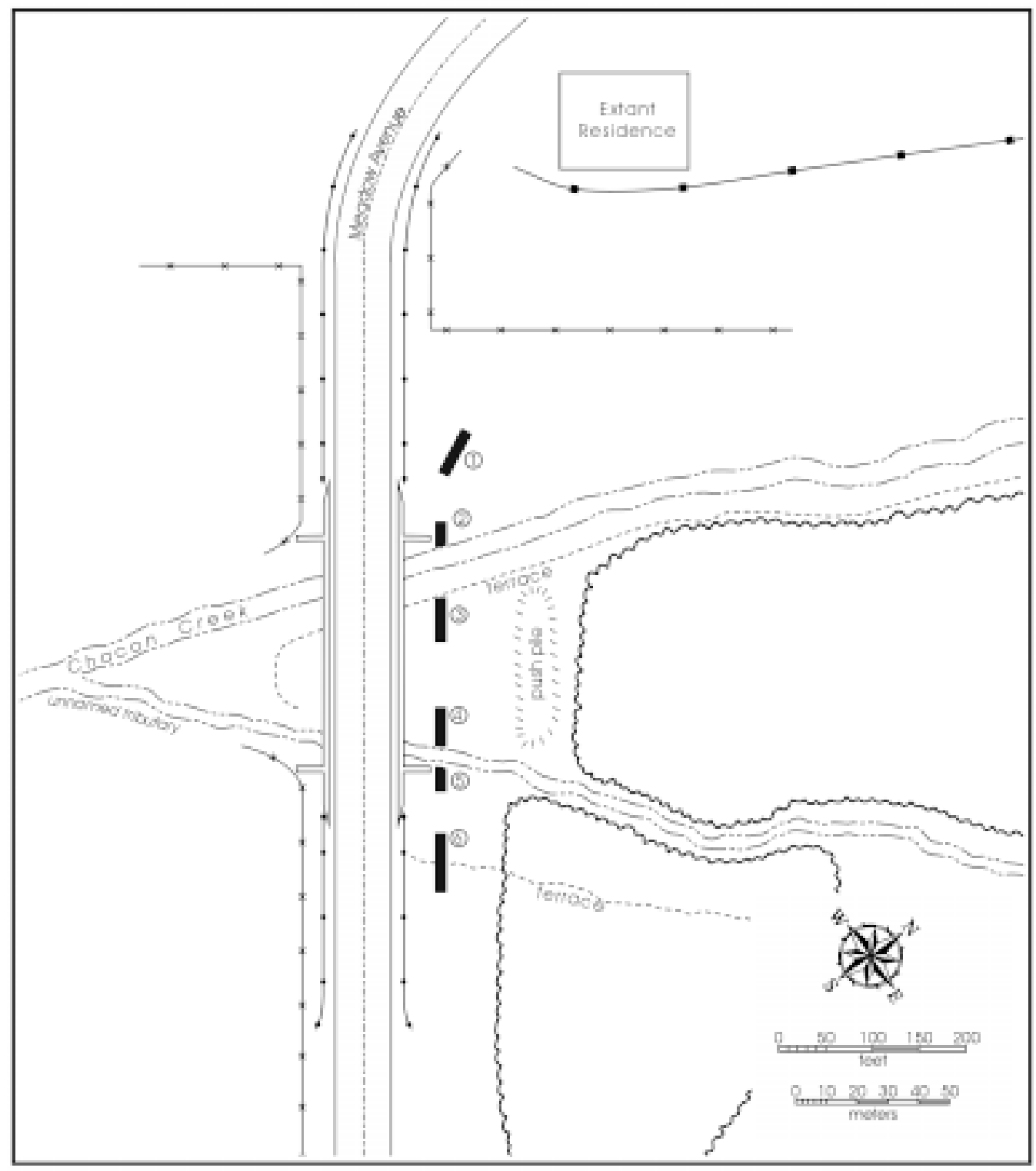

Figure 1. Map of project area with locations of backhoe trenches. 
15 feet $(4.6 \mathrm{~m})$ in depth where it would bore under the existing channels of Chacon Creek. The proposed north and south ends of the utility route are to be bored under the bridge approach on South Meadow Avenue where the proposed relocated line will be tied into the existing gas line. Chacon Creek is a major tributary which leads to the Rio Grande, and the project area is located within a mile of the confluence of the two waterways. Along similar tributaries numerous archaeological sites have been documented, and it was possible that prehistoric cultural deposits could be encountered in the project area.

\section{Methods}

The six backhoe trenches were monitored, examined for cultural materials, profiled, and photographed by two CAR staff archaeologists. Of the six backhoe trenches, two were placed northwest of Chacon Creek, two on a peninsula between Chacon Creek and an unnamed tributary to Chacon Creek, and two were placed southeast of this unnamed tributary (Figure 1). All trenches were placed on or directly northeast of the proposed utility pipeline route as per Karl Burris and as indicated by orange stakes previously placed along the route. Four of the backhoe trenches were situated immediately beside the banks of the two drainages and then extended outward from these banks to search for buried cultural materials. The six trenches varied in length from $3.8 \mathrm{~m}$ to $9.3 \mathrm{~m}$ and reached depths which ranged from approximately $1.5 \mathrm{~m}$ to $3.4 \mathrm{~m}$.

\section{Results}

Backhoe Trench 1 (BHT 1) $5.0 \mathrm{~m}$ in length encountered the water table at approximately $3.4 \mathrm{~m}$ below the modern surface (Figures 1 and 2). It contained a compact sand. At the northern end of the trench and

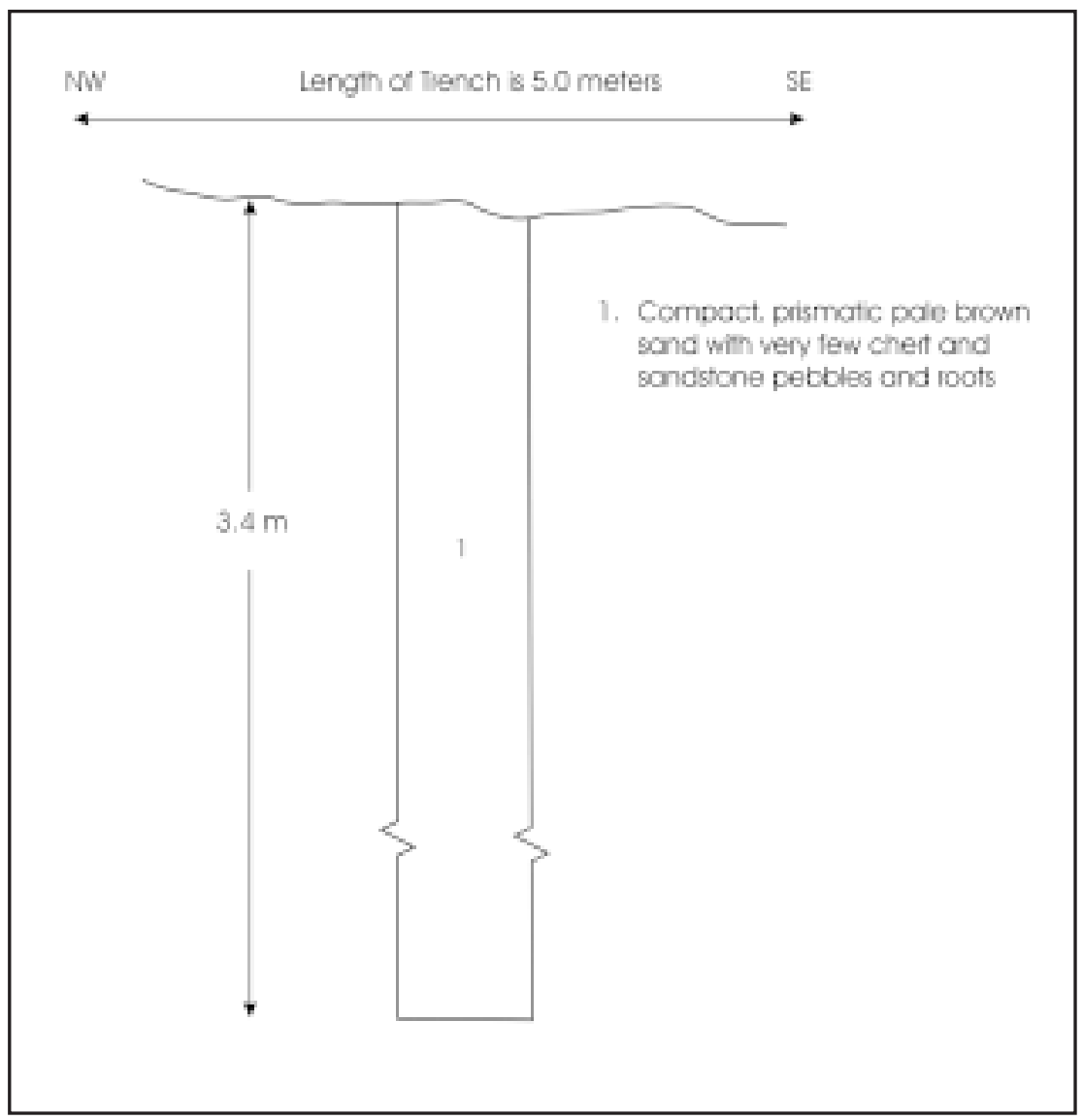

Figure 2. Column profile of east wall of Backhoe Trench 1. 
the base of the terrace slope, the backhoe began to cut into a gravel and brick construction debris mixture with mottled clays. According to the available information this is the area where the bore would begin to go under the existing approach to the bridge.

BHT 2 was placed on the northwest bank of Chacon Creek (Figure 1). It was $6.3 \mathrm{~m}$ in length and multiple layers of sediments were observed in its profile. The matrix consisted of a silty-sand which became generally more compact. A concrete chunk was recovered at $110 \mathrm{~cm}$ below surface.

BHT 3 was $8.2 \mathrm{~m}$ long and cut across a peninsula formed between a tributary and the main channel of Chacon Creek (Figure 1). It appears to be an existing peninsula which has been recently filled with construction debris to cut off the smaller channel of Chacon Creek (Figure 3). The surface of the peninsula had recently been scraped and the vegetation was

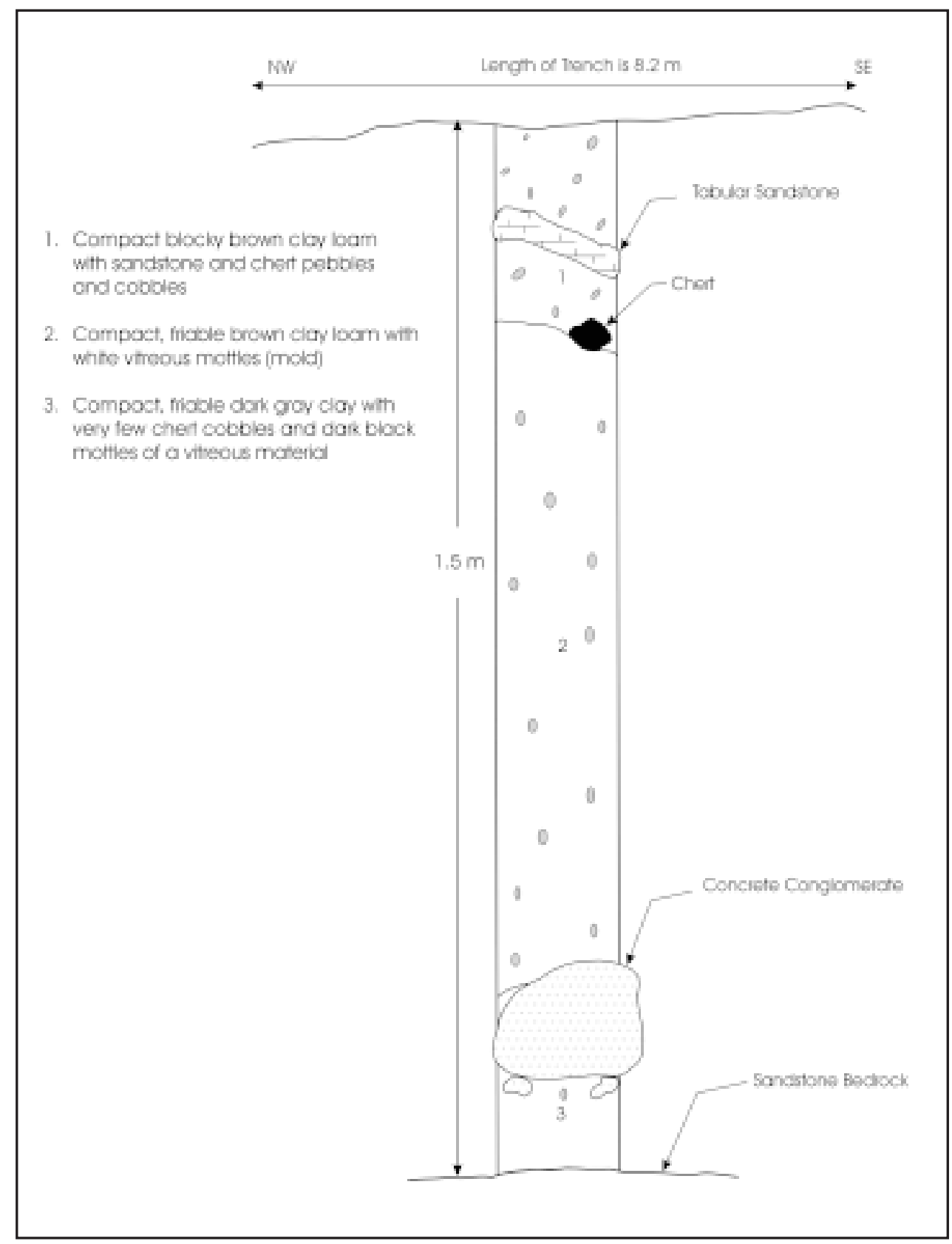

Figure 3. Column profile of east wall of Backhoe Trench 3. 
beginning to grow back. Mr. Burris and Mr. Salinas both confirmed the scraping of the western portion of the area, stating that it had occurred during the past year. The northwest end of BHT 3 was approximately $5 \mathrm{~m}$ from the bank of Chacon Creek, and the southeast end was at the high point of the peninsula.

A large conglomerate "boulder" of concrete-like material was found at approximately $135 \mathrm{~cm}$ below surface. It was sitting on sandstone bedrock and may have been placed there during construction of the bridge. The only artifact recovered from the backhoe trenches during the project was found in BHT 3. This artifact was a secondary chert flake found at ca. 37 $\mathrm{cm}$ below surface in association with modern bottle glass and plastic.

BHT 4 was $7.4 \mathrm{~m}$ long and located on the peninsula approximately $2 \mathrm{~m}$ from the northwest bank of the tributary to Chacon Creek (Figure 1). It was excavated to a depth of $130 \mathrm{~cm}$. The top $50 \mathrm{~cm}$ of the profile contained a sandy-silt with roots and small gravels. From $50 \mathrm{~cm}$ to $110 \mathrm{~cm}$ below surface were layers of sand and silty-sand, and at $110 \mathrm{~cm}$ a compact, friable clay was encountered.

BHT 5 was $3.8 \mathrm{~m}$ long and placed near the southeast bank of the tributary to Chacon Creek at the base of the bridge approach slope, approximately $4 \mathrm{~m}$ from the bridge footing (Figure 1). This portion of the landform is made up of fill. The trench was excavated to a depth of $1.7 \mathrm{~m}$ and appears to have been placed directly above an existing utility pipe, which indicates that the area was previously disturbed.

A single chert flake was observed on the surface near BHT 5. It was found on a push-pile made when the area was bladed to remove vegetation and level the "access road" to the creek. This road is utilized by Federal Immigration and Naturalization Border Patrol agents to provide access to the area beneath the bridge.

BHT 6 was $9.4 \mathrm{~m}$ long and excavated to a depth of $1.5 \mathrm{~m}$. It was placed on a terrace above Chacon Creek with the southeast end of the trench cutting into the terrace (Figure 1). The profile of this trench revealed multiple layers of silty-sand, and debris and/or fill (Figure 4). The materials from this trench included construction debris such as asphalt, plastic, glass, and roots. No archaeological materials were recovered.

\section{Recommendations}

The majority of the tested utility route contained indications of recent (within the last fifty years) disturbances. The following types of disturbances were documented: 1) the dumping and burying of modern garbage and construction materials; 2) the dumping and subsequent burial of large conglomerate blocks of concrete and road construction materials (possibly associated with the construction of the existing bridge over Chacon Creek); and 3) alluvial deposits from recent flooding events which have buried multiple layers of modern garbage and road construction debris.

We recommend that no further action or archaeological monitoring for cultural resources be conducted along this proposed route. However, if the pipeline route is modified before and/or during relocation work, we do suggest that further archaeological work be conducted. This suggestion is based on the presence of the single prehistoric chert flake. When this single artifact is combined with the general terrain both upstream and downstream from the bridge, and the knowledge of archaeological sites in similar settings on these first order tributaries in the Rio Grande river valley, plus the presence of intact terraces along Chacon Creek all indications point to the possibility that archaeological deposits may still exist in the immediate vicinity. It is possible that the modern disturbances from the dumping and bridge construction have not had an impact on areas farther away from the bridge, and intact cultural deposits may still be present. 


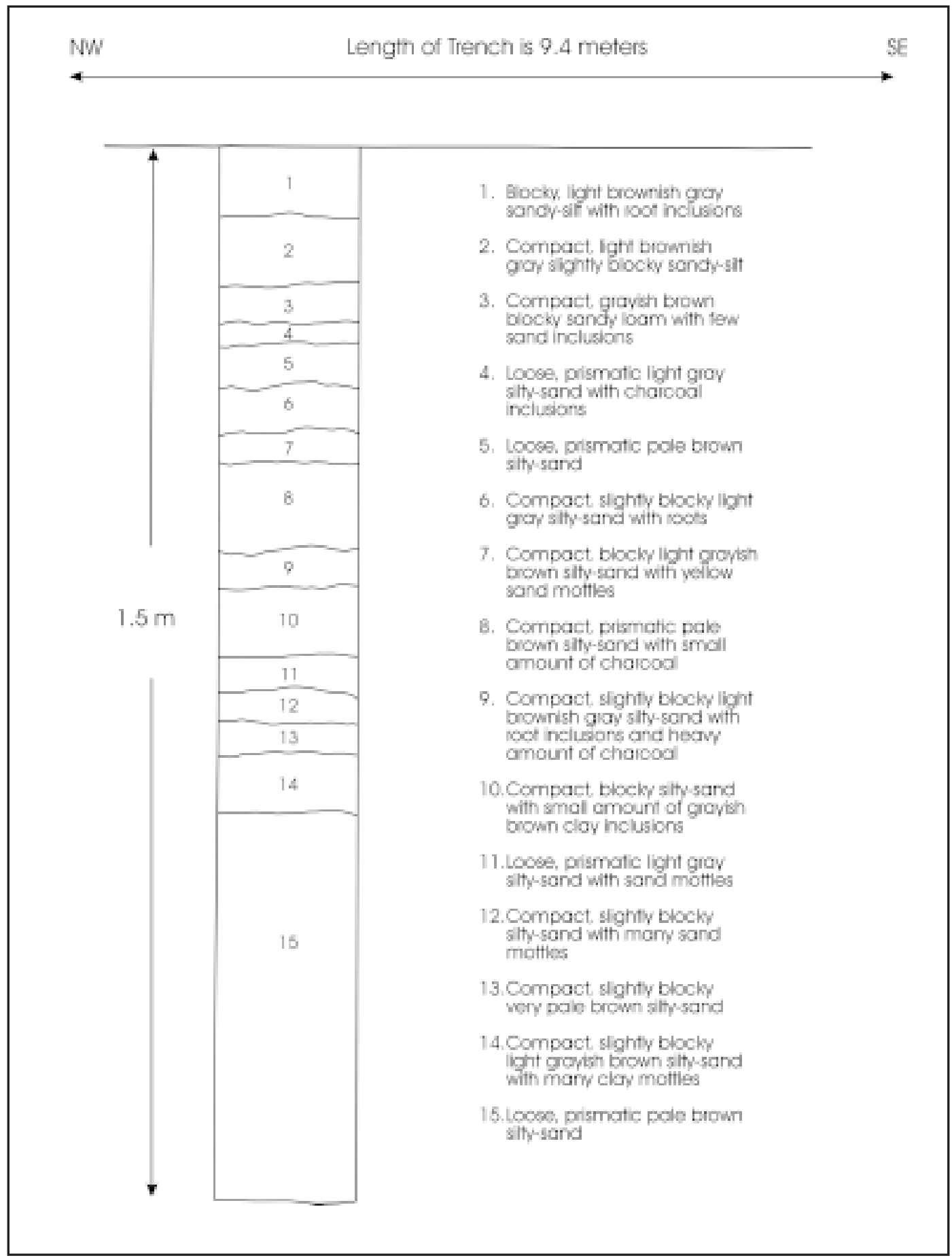

Figure 4. Column profile of east wall of Backhoe Trench 6. 